\title{
Disparities in Healthcare Access and Use: Yackety-yack, Yackety-yack
}

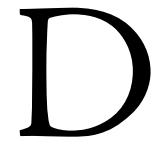

espite change, uncertainty and disarray in Canada's healthcare

system(s), some observations about Canadian medicare still seem beyond challenge:

- access to healthcare based solely on need is the core value that gave rise to and sustains medicare;

- the advent, through medicare, of universal, publicly funded physician and hospital services substantially reduced disparities in access to, and outcomes of, healthcare based on socio-economic status (Enterline et al. 1973; James et al. 2007);

- despite those gains, disparities remain - factors other than need continue to influence access to and use of services.

The last point deserves elaboration. A growing body of research evidence indicates that use of hospital services in Canada is generally consistent with relative need across income groups (e.g., Manga et al. 1987; van Doorslaer and Masseria 2004; Allin 2006). Some studies (van Doorslaer and Masseria 2004; Allin 2006) show greater use of hospital services by those with lower income after controlling for healthcare need perhaps calling into question the adequacy of existing measures of need. On the other hand, studies of specialist services have demonstrated a direct relationship between use and income, education or both (McIsaac et al. 1993, 1997; Roos and Mustard 1997; Dunlop et al. 2000; Finkelstein 2001; van Doorslaer et al. 2006; Allin 2006) - wealthier and better-educated Canadians use more specialist services independent of need.

The picture with respect to primary care physicians' services is less clear. Some studies show an equitable (i.e., needs-based) distribution across education and income groups (McIsaac et al. 1993, 1997; Roos and Mustard 1997; Dunlop et al. 2000), while others do not. For example, Birch et al. (1993) found the use of family physician services to be positively associated with level of education (and extent of contact with friends and relatives). Based on data from the 2001 Canadian Community Health Survey (CCHS), van Doorslaer et al. (2006) found that, after standardizing 
for healthcare need, higher income was associated with a greater likelihood of seeing a primary care physician but a lower number of visits. Using 2003 CCHS data and a similar methodology, Allin (2006) observed a pro-rich inequity in the probability of visiting a family physician, a finding that was inconsistent among the provinces and territories. In the 2002/03 Joint Canada/US Survey of Health, Canadians with low income were less likely to have a regular doctor and more likely to report unmet healthcare needs than those with high income (Lasser et al. 2006). In an earlier international population survey, Canadian respondents with below-average income were more likely than those with above-average income to report having difficulty getting needed care (Shoen et al. 2000).

Data from the 1994/95 National Population Health Survey showed that the likelihood of women in the appropriate age groups having either a Pap smear or a mammogram was associated with higher education level and being born in Canada (Gentleman and Lee 1997; Lee et al. 1998). Income level was also independently associated with having a Pap test (Lee et al. 1998). In the 2005 CCHS, respondents in the highest two (of four) income categories were more likely than those in the lowest income category to report having a flu shot in the previous 12 months (Kwong et al. 2007).

Ontario-based studies have shown a positive association between income and access to coronary angiography and revascularization (Alter et al. 1999) and to inhospital occupational therapy, physiotherapy and speech pathology following a stroke (Kapral et al. 2002). Patients from the lowest-income neighbourhoods waited much longer for coronary angiography (Alter et al. 1999) and carotid artery surgery (Kapral et al. 2002) than those from the highest-income neighbourhoods. Recently published studies in Healthcare Policy/Politiques de Santé point to inequities in access to radiation therapy for breast cancer based on income level (Fortin et al. 2006) and to mental health services for anxiety or depression provided by both family physicians and psychiatrists based on education level (Steele et al. 2007).

This summary, reflecting a brief and unsystematic scan of the literature, describes only the tip of a much larger evidence iceberg. Clearly, Canadian medicare has failed to achieve healthcare access (and use) based on need, even for those services within the purview of the Canada Health Act: hospital and physicians' services. Being poor, poorly educated or both impairs access to specialist and (probably) family physician services, to preventive care (e.g., Pap tests, mammograms and flu shots) and to services for specific health problems (e.g., cardiovascular and mental health).

But income and education are not only associated with access to services; they are themselves determinants of health, and often cluster together with other determinants such as Aboriginal status, early life experiences, employment and working conditions, food security, housing, social exclusion, social safety net, unemployment and employment security (Raphael 2004). The very people who need care the most are the least likely to get the care they need. 
Evidence of the continuing relationship between socio-economic characteristics and access to health services under medicare is abundant, long-standing and persistent. This evidence is without doubt well known (at least in part) to health system decision-makers.

Why, then, is there so little sign of concerted heath policy or health system design and management initiatives at the federal or provincial/territorial levels to address this violation of the fundamental rationale for Canadian medicare? It may be more than coincidence that those on the receiving end of inequitable access are among the least politically and economically powerful members of Canadian society. Although many Canadians are passionately committed to the principle that access to essential health services should be based only on need, they may, given a lack of media and political attention to the issue, assume that the elimination through medicare of (most) financial barriers to obtaining hospital and physicians' services has solved the access problem. Under these circumstances, politicians and governments at the federal and provincial/territorial levels are under little or no pressure to mount a response. As a result, current policy complacency seems likely to continue unless equity of access emerges as a public issue that resonates with Canadians who support the core principles of medicare and mobilizes civil society. Now, there's a challenge for knowledge translation. Meanwhile, there will undoubtedly be lots of talk (research on access inequities and acknowledgment - out of public view - of their existence), but little policy action.

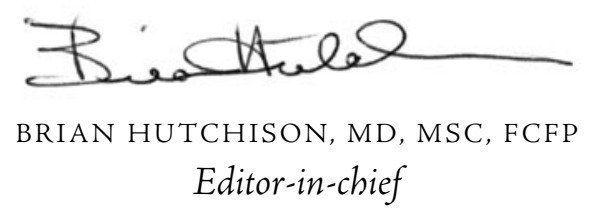

\section{REFERENCES}

Allin, S. 2006 (October). Equity in the Use of Health Services in Canada and Its Provinces. Working Paper No. 3. London, UK: LSE Health.

Alter, D.A., C.D. Naylor, P. Austin and J.V. Tu. 1999."Effects of Socioeconomic Status on Access to Invasive Cardiac Procedures and on Mortality After Acute Myocardial Infarction." New England Journal of Medicine 341(18): 1359-67.

Birch, S., J. Eyles and K.B. Newbold. 1993.“Equitable Access to Health Care: Methodological Extensions to the Analysis of Physician Utilization in Canada." Health Economics 2: 87-101.

Dunlop, S., P. Coyte and W. McIsaac. 2000. "Socio-economic Status and the Utilisation of Physicians' Services: Results from the Canadian National Population Health Survey." Social Science and Medicine 51: 123-33.

Enterline, P.E., V. Slater, A.D. McDonald and J.C. McDonald. 1973.“The Distribution of Medical 
Services Before and After 'Free' Medical Care - The Quebec Experience." New England Journal of Medicine 289: 1174-78.

Finkelstein, M. 2001. “Do Factors Other Than Need Determine Utilization of Physicians' Services in Ontario?" Canadian Medical Association Journal 165(5): 656-70.

Fortin, B., M.S. Goldberg, N.E. Mayo, M-F. Valois, S.C. Scott and J. Hanley. 2006."Waiting Time for Radiation Therapy in Breast Cancer Patients in Quebec from 1992 to 1998." Healthcare Policy/ Politiques de Santé 1(2): 152-67.

Gentleman, J.F. and J. Lee. 1997. “Who Doesn't Get a Mammogram?” Health Reports 9(1): 19-28.

James, P.D., R. Wilkins, A. Detsky, P. Tugwell and D.G. Manuel. 2007."Avoidable Mortality by Neighbourhood Income in Canada: 25 Years After the Establishment of Universal Health Insurance." Journal of Epidemiology and Community Health 61: 287-96.

Kapral, M.K., H. Wong, M. Mamdani and J.V. Tu. 2002."Effect of Socioeconomic Status on Treatment and Mortality After Stroke." Stroke 33: 268-75.

Kwong, J.C., L.C. Rosella and H. Johansen. 2007.“Trends in Influenza Vaccination in Canada, 1996/1997 to 2005." Health Reports 18(4): 1-11.

Lasser, K.E., D.U. Himmelstein and S. Woolhandler. 2006. "Access to Care, Health Status, and Health Disparities in the United States and Canada: Results of a Cross-National PopulationBased Survey". American Journal of Public Health 96(7): 1300-7.

Lee, J., G.F. Parsons and J.F. Gentleman. 1998. “Falling Short of Pap Test Guidelines.” Health Reports 10(1): 9-19.

Manga, P., W. Broyles and D.E. Angus. 1987.“The Determinants of Hospital Utilization Under a Universal Public Insurance Plan in Canada." Medical Care 25(7): 658-70.

McIsaac, W.J., V. Goel and C.D. Naylor. 1993 (October). The Utilization of Physician Services in Ontario by Adults: Results from the Ontario Health Survey. ICES Working Paper \#20. Toronto: Institute for Clinical Evaluative Sciences.

McIsaac, W., V. Goel and D. Naylor. 1997. "Socio-economic Status and Visits to Physicians by Adults in Ontario, Canada." Journal of Health Services Research and Policy 2(2): 94-102.

Raphael, D. 2004. "Introduction to the Social Determinants of Health." In D. Raphael, ed., Social Determinants of Health: Canadian Perspectives (pp. 1-18). Toronto: Canadian Scholars' Press.

Roos, N.P. and C.A. Mustard. 1997."Variation in Health and Health Care Use by Socioeconomic Status in Winnipeg, Canada: Does the System Work Well? Yes and No." Milbank Quarterly 75(1): 89-111.

Shoen, C., K. Davis, C. DesRoches, K. Donelan and R. Blendon. 2000."Health Insurance Markets and Income Inequality: Findings from an International Health Policy Survey." Health Policy 51: 67-85.

Steele, L.S., C.S. Dewa, E. Lin and K.L.K. Lee. 2007."Education Level, Income Level and Mental Health Services Use in Canada: Associations and Policy Implications." Healthcare Policy/Politiques de Santé 3(1): 96-106.

van Doorslaer, E. and C. Masseria. 2004. Income-Related Inequality in the Use of Medical Care in 21 OECD Countries. Paris: Organisation for Economic Co-operation and Development.

van Doorslaer, E., C. Masseria and X. Koolman. 2006. "Inequalities in Access to Medical Care by Income in Developed Countries." Canadian Medical Association Journal 174(2): 177-83. 


\section{Disparité dans l'accès aux soins de santé et dans leur utilisation : encore du bla-bla}

$\mathrm{E}$ N DÉPIT DES CHANGEMENTS, DE L'inCERTITUde ET DE LA CONFUSION QUi affectent le système de soins de santé au Canada, certaines observations concernant le régime d'assurance-maladie canadien semblent toujours incontestables :

- Laccès aux soins de santé accordé uniquement en fonction des besoins est la valeur fondamentale qui a fait naître le régime d'assurance-maladie et qui le soutient.

- Lapparition, grâce au régime d'assurance-maladie, de services hospitaliers et médicaux universels financés par l'État a substantiellement réduit les disparités dans l'accès aux soins médicaux, ainsi que dans leurs résultats, entre les gens de statut socio-économique différent (Enterline et coll., 1973, James et coll., 2007).

- Malgré ces gains, on constate encore des disparités; le besoin n'est toujours pas le seul facteur qui détermine l'accès et l'utilisation des services.

Ce dernier point mérite plus d'explications. Les conclusions d'un nombre toujours croissant de recherches sur la question indiquent que le recours aux services hospitaliers au Canada correspond habituellement au besoin relatif peu importe la catégorie de revenu (Manga et coll., 1987, van Doorslaer et Masseria, 2004, Allin, 2006, etc.). Certaines études (van Doorslaer et Masseria, 2004, Allin, 2006) révèlent que les personnes au revenu plus faible font une plus grande utilisation des services hospitaliers proportionnellement à leurs besoins (ce qui peut soulever des questions sur l'exactitude des mesures existantes du besoin). D'autre part, les études concernant les services des spécialistes ont établi une relation directe entre l'utilisation des services et le revenu, le niveau d'instruction ou les deux (McIsaac et coll., 1993, 1997, Roos et Mustard, 1997, Dunlop et coll., 2000, Finkelstein, 2001, van Doorslaer et coll., 2006, Allin, 2006); ainsi, les membres plus riches et instruits de notre société ont plus souvent recours aux services de spécialistes, indépendamment de leur besoin réel.

La situation n'est pas aussi claire en ce qui concerne les services des médecins de premier recours. Certaines études indiquent qu'il sen fait une utilisation équitable (c.-à-d. en fonction des besoins) dans toutes les catégories de revenu et d'instruction (McIsaac et coll., 1993, 1997, Roos et Mustard, 1997, Dunlop et coll., 2000), alors que d'autres disent le contraire. Birch et coll. (1993) ont établi un lien positif entre le recours aux services des médecins de famille et le niveau d'instruction (ainsi que le degré de contact avec les amis et les parents). En sappuyant sur les données de l'Enquête sur la santé dans les collectivités canadiennes (ESCC) de 2001, van 
Doorslaer et coll., (2006) ont découvert, après normalisation des besoins en soins de santé, qu'une personne au revenu plus élevé était plus susceptible de consulter un médecin de premier recours, mais que ses visites étaient moins nombreuses. Utilisant une méthode similaire et les données de l'ESCC de 2003, Allin (2006) a observé une certaine inégalité, en ce sens que les gens mieux nantis sont plus susceptibles de consulter un médecin, bien que cette inégalité ne soit pas constante dans toutes les provinces et tous les territoires. Selon l'Enquête conjointe Canada/États-Unis sur la santé de 2002-2003, les Canadiens à faible revenu sont proportionnellement moins nombreux à avoir un médecin de famille et rapportent plus souvent des besoins insatisfaits en soins de santé que ceux à revenu élevé (Lasser et coll., 2006). Dans une étude internationale antérieure sur la population, les répondants canadiens au revenu inférieur à la moyenne faisaient plus souvent état de difficultés dans l'obtention des soins dont ils avaient besoin que ceux au revenu supérieur à la moyenne (Shoen et coll., 2000).

Les données de l'Enquête nationale sur la santé de la population de 1994-1995 ont démontré que les chances qu'une femme appartenant à un des groupes d'âge concernés passe un test de Papanicolaou ou une mammographie augmentent avec le niveau d'instruction et le fait d'être née au Canada (Gentleman et Lee, 1997; Lee et coll., 1998). Le niveau de revenu a aussi été associé indépendamment avec la probabilité de se soumettre à un test de Papanicolaou (Lee et coll., 1998). De plus, à l'ESCC de 2005, les répondants des deux catégories de revenu les plus élevées (sur quatre) étaient proportionnellement plus nombreux que ceux de la catégorie de revenu inférieure à mentionner avoir reçu un vaccin antigrippal au cours des 12 mois précédents (Kwong et coll., 2007).

Des études ontariennes ont démontré qu'il y a une association positive entre le revenu et l'accès à la coronarographie et à la revascularisation (Alter et coll., 1999), ainsi quà l'ergothérapie, à la physiothérapie et à l'orthophonie en milieu hospitalier à la suite d'un accident cérébrovasculaire (Kapral et coll., 2002). Les patients des quartiers les plus pauvres doivent attendre beaucoup plus longtemps avant d'obtenir une coronarographie (Alter et coll., 1999) ou une chirurgie de l'artère carotide (Kapral et coll., 2002) que ceux des quartiers les plus riches. Des études publiées récemment dans Healthcare Policy/Politiques de Santé semblent indiquer des inégalités dans l'accès à la radiothérapie pour les cas de cancer du sein au Québec en fonction du niveau de revenu (Fortin et coll., 2006) et dans l'accès aux services de santé mentale, selon le niveau d'instruction, pour les Canadiens qui souffrent d'angoisse ou de dépression, et ce, autant auprès des médecins de famille que des psychiatres (Steele et coll., 2007).

Ce compte rendu sommaire, basé sur un survol rapide et peu systématique de la documentation, ne révèle que la pointe d'un iceberg bien plus imposant de preuves. De toute évidence, le régime d'assurance-maladie du pays ná pas réussi à garantir l'accès aux soins de santé (et leur utilisation) en fonction des besoins, même dans le cas des services hospitaliers et de médecins, pourtant touchés par la Loi canadienne 
sur la santé. Le fait d'être pauvre ou d'avoir peu d'instruction, ou les deux, constitue un obstacle à l'accès aux services d'un spécialiste et même, généralement, d'un médecin de famille, aux soins préventifs (p. ex., test de Papanicolaou, mammographie et vaccin antigrippal) et aux services médicaux concernant des problèmes précis (p. ex., maladies cardiovasculaires et problèmes de santé mentale).

Cela dit, le revenu et l'instruction n'ont pas seulement une incidence sur l'accès aux services. Il sagit en soi de facteurs déterminants pour la santé, souvent liés à d'autres facteurs déterminants comme l'appartenance à un groupe autochtone, les expériences de jeunesse, l'emploi et les conditions de travail, la sécurité alimentaire, le logement, l'exclusion sociale, la protection sociale, le chômage et la sécurité d'emploi (Raphael, 2004). Dans les faits, les personnes qui ont le plus besoin de soins sont celles qui ont le moins de chances d'obtenir les soins dont elles ont besoin.

On peut donc se demander pourquoi on attend toujours des signes de concertation sur le plan des politiques, de la conception du système et des initiatives de gestion en santé, que ce soit au palier fédéral ou provincial et territorial, dans le but de corriger ce non-respect des fondements du régime canadien d'assurance-maladie. Ce n'est peut-être pas une coïncidence si ceux qui ne jouissent pas d'un accès équitable aux soins de santé sont aussi les membres les moins influents, économiquement et politiquement, de la société canadienne. De nombreux Canadiens croient fermement dans le principe qui veut que le besoin de services essentiels de santé soit le seul facteur qui y détermine l'accès. Malheureusement, étant donné le manque d'attention que portent les politiciens ou les médias à la question, la population peut croire à tort que l'élimination par le régime d'assurance-maladie (de la plupart) des barrières économiques à l'obtention de services médicaux a résolu le problème d'accès aux soins. Dans ces circonstances, les politiciens et les gouvernements des paliers fédéral et provincial/territorial ne sentent aucunement de pression pour réagir à cette situation. L'indifférence politique actuelle risque fort de continuer à moins qu'on parvienne à rassembler l'opinion publique sur la question de l'égalité d'accès aux soins et à mobiliser les Canadiens qui appuient les principes fondamentaux du régime d'assurancemaladie. Ça, ćest tout un défi sur le plan de l'application des connaissances. D'ici à ce qu'on y parvienne, il y aura sans doute encore beaucoup de discussions (recherches sur les inégalités en matière d'accès et reconnaissance, en secret, de leur existence), mais très peu d'initiatives politiques.

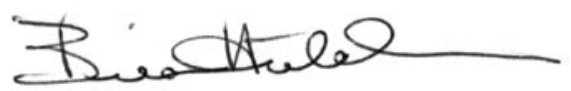

BRIAN HUTCHISON, MD, MSC, FCFP

Rédacteur en chef 


\section{RÉFÉRENCES}

Allin, S. 2006 (octobre). Equity in the Use of Health Services in Canada and Its Provinces. Document de travail no 3. Londres, R.-U. : LSE Health.

Alter, D.A., C.D. Naylor, P. Austin et J.V. Tu. 1999. « Effects of Socioeconomic Status on Access to Invasive Cardiac Procedures and on Mortality After Acute Myocardial Infarction. » New England Journal of Medicine 341(18) : 1359-67.

Birch, S., J. Eyles et K.B. Newbold. 1993. « Equitable Access to Health Care: Methodological Extensions to the Analysis of Physician Utilization in Canada. » Health Economics 2:87-101.

Dunlop, S., P. Coyte et W. McIsaac. 2000. « Socio-economic Status and the Utilisation of Physicians' Services: Results from the Canadian National Population Health Survey. » Social Science and Medicine $51: 123-33$.

Enterline, P.E., V. Slater, A.D. McDonald et J.C. McDonald. 1973. «The Distribution of Medical Services Before and After 'Free' Medical Care - The Quebec Experience. » New England Journal of Medicine 289 : 1174-78.

Finkelstein, M. 2001. « Do Factors Other Than Need Determine Utilization of Physicians' Services in Ontario? » Journal de l'Association médicale canadienne 165(5) : 656-70.

Fortin, B., M.S. Goldberg, N.E. Mayo, M-F. Valois, S.C. Scott et J. Hanley. 2006. « Temps d'attente pour la radiothérapie chez les femmes atteintes de cancer du sein au Québec de 1992 à 1998. » Healthcare Policy/Politiques de Santé 1(2) : 152-67.

Gentleman, J.F. et J. Lee. 1997. «Qui ne se fait pas mammographier? » Rapports sur la santé 9(1): 19-28.

James, P.D., R. Wilkins, A. Detsky, P. Tugwell et D.G. Manuel. 2007. « Avoidable Mortality by Neighbourhood Income in Canada: 25 Years After the Establishment of Universal Health Insurance. » Journal of Epidemiology and Community Health 61 : 287-96.

Kapral, M.K., H. Wong, M. Mamdani et J.V. Tu. 2002. « Effect of Socioeconomic Status on Treatment and Mortality After Stroke. » Stroke $33: 268-75$.

Kwong, J.C., L.C. Rosella et H. Johansen. 2007. « Tendances de la vaccination contre la grippe au Canada, 1996-1997 à 2005. » Rapports sur la santé 18(4) : 1-11.

Lasser, K.E., D.U. Himmelstein et S. Woolhandler. 2006. « Access to Care, Health Status, and Health Disparities in the United States and Canada: Results of a Cross-National PopulationBased Survey. » American Journal of Public Health 96(7) : 1300-7.

Lee, J., G.F. Parsons et J.F. Gentleman. 1998, « Le non-respect des lignes directrices quant au test de Papanicolaou. » Rapport sur la santé 10(1) : 9-19.

Manga, P., W. Broyles et D.E. Angus. 1987. «The Determinants of Hospital Utilization Under a Universal Public Insurance Plan in Canada. » Medical Care 25(7) : 658-70.

McIsaac, W.J., V. Goel et C.D. Naylor. 1993 (octobre). The Utilization of Physician Services in Ontario by Adults: Results from the Ontario Health Survey. Document de travail no 20 de l'IRSS.

Toronto : Institut de recherche en services de santé.

McIsaac, W., V. Goel et D. Naylor. 1997. « Socio-economic Status and Visits to Physicians by Adults in Ontario, Canada. » Journal of Health Services Research and Policy 2(2) : 94-102.

Raphael, D. 2004. «Introduction to the Social Determinants of Health. » In Social Determinants of Health: Canadian Perspectives, sous la direction de D. Raphael, p. 1-18. Toronto : Canadian Scholars' Press. 
Roos, N.P. et C.A. Mustard. 1997. « Variation in Health and Health Care Use by Socioeconomic Status in Winnipeg, Canada: Does the System Work Well? Yes and No. » Milbank Quarterly 75(1) : 89-111.

Shoen, C., K. Davis, C. DesRoches, K. Donelan et R. Blendon. 2000, « Health Insurance Markets and Income Inequality: Findings from an International Health Policy Survey. » Health Policy 51 : 67-85.

Steele, L.S., C.S. Dewa, E. Lin et K.L.K. Lee. 2007. « Niveau de scolarité, niveau de revenu et utilisation des services de santé mentale au Canada : répercussions sur les associations et les politiques, » Healthcare Policy/Politiques de Santé 3(1) : 96-106.

van Doorslaer, E. et C. Masseria. 2004. Inégalité liée au revenu dans le recours aux soins dans 21 pays de l'OCDE. Paris : Organisation de coopération et de développement économiques.

van Doorslaer, E., C. Masseria et X. Koolman. 2006. «Inequalities in Access to Medical Care by Income in Developed Countries, » Journal de l'Association médicale canadienne 174(2) : 177-83.

\section{Chief Executive Officer}

Healthcare systems around the world continue to embrace the use and value of scientific evidence in all forms of decisionmaking. Recognized internationally as a leader and innovator in promoting the scientific basis of health services, the Canadian Health Services Research Foundation is bridging the gaps between research and healthcare management and policy across the country.

As Chief Executive Officer, supporting the Board of Trustees, you will continue a tradition of innovation, and help steer the Foundation in new and exciting directions. With your guidance, and that of the Board, the Foundation will help shape and define how healthcare management and policy are formulated in the years ahead. To this end, you will encourage debate and dialogue among stakeholders from the research, policy, and management communities in an effort to enhance their linkages and exchanges. Looking to the future, you will work closely with governments and stakeholders to secure ongoing commitment and support for the Foundation's mission.

A passionate leader and enthusiastic manager, you will mentor a talented and committed team and steward an endowment of approximately $\$ 100$ million. You are a credible and respected voice for applied research, with strong networks in academia, government and administration. A driver of change, you are committed to improving health systems through excellence and innovation. You are a gifted communicator and relationship builder who can move and inspire people across various disciplines and sectors to work together. You are comfortable in a range of settings, small and large, national and international. Your proficiency, or willingness to readily become proficient, in both official languages is required in this truly pan-Canadian role.

To explore this unique leadership opportunity further, please contact Michael Naufal in our Ottawa office at (613) 742-3198 or send your resume in complete confidence to michael.naufal@rayberndtson.ca

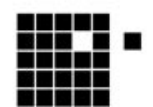

RAY \& BERNDTSON Global Leaders in Executive Search 